\title{
Pulmonary Hypertension in the Population with Down Syndrome
}

Douglas S. Bush (D) - D. Dunbar Ivy

Received: October 22, 2021 / Published online: January 16, 2022

(C) The Author(s) 2022

\begin{abstract}
Persons with Down syndrome (DS) have an increased reported incidence of pulmonary hypertension (PH). A majority of those with $\mathrm{PH}$ have associations with congenital heart disease (CHD) or persistent pulmonary hypertension of the newborn (PPHN); however, there are likely multifactorial contributions that include respiratory comorbidities. $\mathrm{PH}$ appears to be most commonly identified early in life, although respiratory challenges may contribute to a later diagnosis or even a recurrence of previously resolved $\mathrm{PH}$ in this population. Currently there are few large-scale, prospective, lifetime cohort studies detailing the impact $\mathrm{PH}$ has on the population with DS. This review will attempt to summarize the epidemiology and characteristics of $\mathrm{PH}$ in this population. This article will additionally review current known and probable risk factors for developing $\mathrm{PH}$, review pathophysiologic mechanisms of disease in the
\end{abstract}

\section{S. Bush $(\square)$}

Department of Pediatrics, Division of Pulmonology, Icahn School of Medicine at Mount Sinai, One Gustave L. Levy Place, Box 1202B, New York, NY 10029, USA

e-mail: douglas.bush@mssm.edu

D. D. Ivy

Department of Pediatrics, Division of Cardiology, University of Colorado School of Medicine, Aurora, CO, USA population with DS, and evaluate current screening and management recommendations while suggesting areas for additional or ongoing clinical, translational, and basic science research.

Keywords: Down syndrome; Trisomy 21; Pulmonary hypertension; Pulmonary arterial hypertension; Congenital heart disease

\section{Key Summary Points}

Pulmonary hypertension is a common comorbidity in the population with Down syndrome, frequently with multifactorial etiologies including congenital heart disease, developmental lung disease, and other respiratory pathologies.

Screening for pulmonary hypertension in the population with DS remains challenging, but novel biomarkers are currently being investigated.

Understanding the etiology of pulmonary hypertension in the population with Down syndrome can help guide treatment strategies. 


\section{INTRODUCTION}

Pulmonary hypertension (PH) is frequently identified in individuals with Down syndrome (DS). The high frequency of PH in this population has probable genetic (Table 1), congenital, and environmental contributions [1]. While the lifetime prevalence remains unknown, reports of $\mathrm{PH}$ incidence in childhood may be as high as $28 \%$ in this population [2]. The etiology of $\mathrm{PH}$ in persons with DS varies; however, there is a strong association with congenital heart disease (CHD), which is present in $38-58 \%$ of this population [3-6]. Those without CHD also appear to be at higher risk of developing $\mathrm{PH}$ when compared to the general population, and there are likely additional respiratory and cardiovascular reasons for this increase [1].

The World Symposium on Pulmonary Hypertension (WSPH) classifies $\mathrm{PH}$ into five major groups including pulmonary arterial hypertension (PAH; Group 1); PH due to leftsided heart disease (Group 2); PH due to lung disease or hypoxia (Group 3); chronic thromboembolic PH (CTEPH; Group 4) and PH due to multifactorial, mixed or unclear mechanisms (Group 5) [7]. Many reports of $\mathrm{PH}$ in persons with DS attribute the $\mathrm{PH}$ to Group $1 \mathrm{PAH}$; however, there are likely underreported contributions from left heart disease, disorders of the

Table 1 Possible genetic contributions to the development of pulmonary hypertension in Down syndrome

\begin{tabular}{|c|c|c|}
\hline Contribution to $\mathbf{P H}$ & Gene & Protein \\
\hline \multicolumn{3}{|l|}{ Hemodynamic stress } \\
\hline \multicolumn{3}{|c|}{ Congenital heart disease } \\
\hline$(\mathrm{AVSD})$ & CRELDI & Cysteine-rich with EGF-like domain protein 1 \\
\hline \multirow[t]{6}{*}{ (VSD) } & $H E Y 2$ & Hairy/enhancer-of-split related with YRPW motif protein 2 \\
\hline & GATA3 & (Transcription factor) \\
\hline & $K C N H 2$ & Kv11.1 \\
\hline & $E N G$ & Endoglin \\
\hline & $F L N A$ & Filamin A \\
\hline & $G U S B$ & Beta-glucuronidase \\
\hline \multicolumn{3}{|l|}{ Pulmonary hypoplasia } \\
\hline \multicolumn{3}{|l|}{ Antiangiogenesis } \\
\hline & RCANI & Regulator of calcineurin-1 \\
\hline & COL18al & Endostatin \\
\hline & $A P P$ & Amyloid beta protein \\
\hline \multicolumn{3}{|l|}{ Endothelial dysfunction } \\
\hline \multirow[t]{4}{*}{ Proinflammatory } & IFNARI & Interferon-alpha/beta receptor 1 \\
\hline & IFNAR2 & Interferon-alpha/beta receptor 2 \\
\hline & IFNGR2 & Interferon-gamma receptor 2 \\
\hline & ILIORB & Interleukin-10 receptor subunit beta \\
\hline
\end{tabular}

$A V S D$ atrioventricular septal defect, $V S D$ ventricular septal defect 
lung, and complex CHD (Group 5-category that includes segmental pulmonary hypertension, single ventricle disorders, and Scimitar syndrome) [8]. As such, a better understanding of the etiology of $\mathrm{PH}$ in the population with DS is necessary to help determine appropriate screening and interventions. This review will serve as a critical evaluation of the current literature, will provide ideas for interim strategies to help manage cardiopulmonary challenges in persons with DS and will offer suggestions for future research. This manuscript is based on previously conducted studies and does not contain any new studies with human participants or animals performed by any of the authors.

\section{EPIDEMIOLOGY}

A recent meta-analysis reported that the average life expectancy for individuals with DS is approximately 30 years less than individuals without DS. In this analysis, cardiovascular disorders accounted for 1.5-24\%, cardiac failure $18.8-33 \%$, and CHD accounting for $3-50 \%$ of deaths in this population [9]. A large population study using data from the US Centers for Disease Control and Prevention National Center for Health Statistics reported increased odds of death (odds ratio 3.83 with 95\% CI 3.60-4.07) from pulmonary vascular disease in persons with DS between 1983 and 1997 [10]. These findings suggest the burden of pulmonary vascular disease is higher in the population with DS.

There are few large cohort studies evaluating the lifetime incidence of $\mathrm{PH}$ in individuals with DS from all causes. One moderate-sized $(n=1242), \quad$ single-institution, retrospective study suggested that childhood incidence of $\mathrm{PH}$ is as high as $28 \%$, increasing to $45 \%$ in the presence of CHD [2]. The vast majority of studies have evaluated the incidence of $\mathrm{PH}$ classified as Group 1, primarily PAH associated with CHD or persistent pulmonary hypertension of the newborn (PPHN; Group 1.7). PPHN has been reported to occur at a rate of $1.2-9.7 \%$ in the population with DS $(0.1 \%$ in the general population), perhaps suggesting an innate abnormality in vasoactive regulation or airway structure associated with the overexpression of human chromosome 21-related genes [2, 11].

The timing of $\mathrm{PH}$ onset appears to most commonly occur in the first year of life, particularly with PPHN and in the presence of CHD $[2,12]$. In one moderate-sized retrospective study, $70 \%$ of children with $\mathrm{PH}$ experienced transient disease with resolution following interventions, a small portion (15\%) experienced persistent $\mathrm{PH}$, and a similar amount (15\%) developed recurrence of $\mathrm{PH}$, frequently as a result of respiratory comorbidities [2]. The average age of recurrence was 1.7 years in this study, suggesting that $\mathrm{PH}$ may be most challenging early in life in the population with DS. In another small $(n=102)$ prospective study, the prevalence of $\mathrm{PH}$ in DS was $5.9 \%$ at 1 year and $15 \%$ at 10 years, although the study appears to have been evaluating older children (mean age $16.4 \pm 12$ years) without surgically corrected $\mathrm{CHD}$, complicating our understanding of the condition [3].

The need for specialty providers and expensive invasive (cardiac catheterization) or noninvasive (echocardiography) testing to identify PH may have historically hindered a thorough understanding of the incidence of $\mathrm{PH}$ in this population. Further, pulmonary hypertension is not always symptomatic, and early recognition of the disease may be limited in more sedentary populations or those who are unable to comply with clinical assessments (e.g., exercise testing or 6-minute walk distance testing), underestimating the population prevalence of $\mathrm{PH}$. There may even be bias against evaluating for the condition in specialty practices without echocardiography (e.g., pulmonology) or failure to recognize the condition in the setting of other CHD (e.g., left heart disease or complex cardiac disease) and thus an underreporting of disease prevalence. Further, in 2018, the Pediatric Task Force of the 6th World Symposium on Pulmonary Hypertension (WSPH; Nice, France, 2018) revised the definition of $\mathrm{PH}$, reducing the diagnostic threshold of mean pulmonary arterial pressure (mPAP) from 25 to $20 \mathrm{mmHg}$, as studies placed this more than two standard deviations above the population mean [13]. Prior studies have used the higher mPAP 
threshold, likely reducing the reported incidence of $\mathrm{PH}$. Thus, a better understanding of $\mathrm{PH}$ disease incidence and prevalence in the population with DS is needed.

\section{CLASSIFICATION, ETIOLOGY, AND RISK FACTORS}

Pulmonary hypertension develops when pulmonary arterial pressure increases in order to maintain blood flow in the presence of the increased pulmonary vascular resistance that occurs due to vascular remodeling (Ohm's law). The etiology of pulmonary hypertension in individuals with Down syndrome is not always straightforward and can often be attributed to multiple underlying challenges to the pulmonary vascular system including increases in hemodynamic stress, abnormalities in lung development, intrinsic endothelial dysfunction, increases in pulmonary vascular resistance, and post-capillary disease (Fig. 1). Large prospective studies evaluating etiologies of $\mathrm{PH}$ in the population with DS are lacking; however, a thorough literature review has revealed known and likely risk factors for developing PH (Table 2).

Individuals with Down syndrome very often fit into multiple $\mathrm{PH}$ classification categories (Table 3). The most common classification is Group 1, PAH associated with either CHD or PPHN; however, there are frequent contributions from left heart inflow or outflow disease (Group 2), respiratory challenges from chronic or intermittent hypoxia (Group 3), and occasionally complex cardiac disease (Group 5) or metabolic derangements such as hypothyroidism (Group 5). Given the complexity of classifying $\mathrm{PH}$ in DS, the WSPH has recommended that in the absence of CHD, individuals with DS who have PH should be categorized as Group 3 disease due to the high frequency of associated respiratory challenges [13].

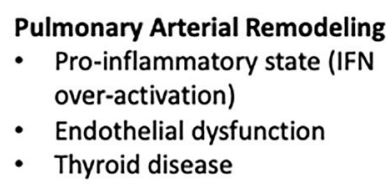

Pulmonary Arterial Remodeling Pro-inflammatory state (IFN

- Thyroid disease

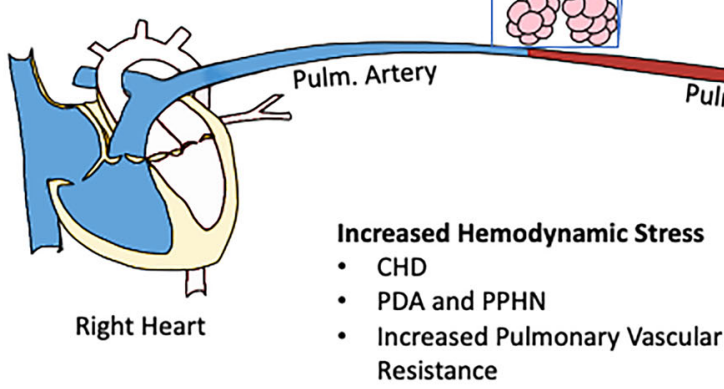

Increased Pulmonary Vascular Resistance

- Alveolar Simplification

- Obstructive Sleep Apnea

- Acquired Lung Disease

- Post-capillary Disease

pulmonary hypertension of the newborn (PPHN) in developmentally immature lungs with high pulmonary vascular resistance. Increased pulmonary vascular resistance can occur from acquired lung disease and capillary or postcapillary disorders
Fig. 1 Pathophysiology and etiologies of development of pulmonary hypertension in Down syndrome. Early pulmonary arterial remodeling may occur due to an innate interferonopathy, intrinsic endothelial dysfunction or other metabolic conditions. Increases in hemodynamic stress can occur from congenital heart disease (CHD) or patent ductus arteriosus (PDA) causing persistent 
Table 2 Comorbid conditions and reported frequencies in the population with DS (modified from Bush et al. Ped Pulm, 2019) [57]

\begin{tabular}{|c|c|c|c|}
\hline & $\%$ in DS & \% in DS with PH [2] & Relative risk for $\mathrm{PH}(95 \% \mathrm{CI})$ [2] \\
\hline \multicolumn{4}{|l|}{ Cardiac conditions } \\
\hline $\mathrm{CHD}$ & $40-75$ & 94.2 & $5.3(3.5-8.2)$ \\
\hline $\mathrm{CHD}$ with L-to- $\mathrm{R}$ shunt & 35.1 & 59.8 & $2.1(1.7-2.5)$ \\
\hline AVSD & $9-49$ & 19.9 & $1.6(1.3-1.9)$ \\
\hline VSD & $26-35$ & 32 & $1.8(1.5-2.1)$ \\
\hline ASD & $2-38$ & 46.2 & $1.9(1.6-2.3)$ \\
\hline PDA & $3-47$ & 59.8 & $1.6(1.3-1.9)$ \\
\hline CHD without L-to-R shunt & 7.2 & 4.6 & $1.4(1.3-1.9)$ \\
\hline \multicolumn{4}{|l|}{ Pulmonary conditions } \\
\hline Pulmonary hypoplasia & * & $\mathrm{N} / \mathrm{A}$ & $\mathrm{N} / \mathrm{A}$ \\
\hline OSA & $45-79$ & 77.5 & $\mathrm{~N} / \mathrm{A}$ \\
\hline Intermittent or chronic hypoxia & * & 55.5 & $\mathrm{~N} / \mathrm{A}$ \\
\hline Recurrent pneumonia & * & 43.1 & $\mathrm{~N} / \mathrm{A}$ \\
\hline Aspiration & $35-39$ & 35.5 & $\mathrm{~N} / \mathrm{A}$ \\
\hline Asthma & $32-36$ & 20.5 & $\mathrm{~N} / \mathrm{A}$ \\
\hline Chronic lung disease/BPD & * & 19.9 & $\mathrm{~N} / \mathrm{A}$ \\
\hline Tracheobronchomalacia & $3-33$ & 15.9 & $\mathrm{~N} / \mathrm{A}$ \\
\hline Tracheal bronchus & $3-5$ & & \\
\hline Subglottic stenosis & $4-6$ & 8.4 & $\mathrm{~N} / \mathrm{A}$ \\
\hline Laryngomalacia & $*$ & 7.8 & N/A \\
\hline \multicolumn{4}{|l|}{ Metabolic conditions } \\
\hline Thyroid abnormalities & 27 & 32.1 & $\mathrm{~N} / \mathrm{A}$ \\
\hline \multicolumn{4}{|l|}{ Gastrointestinal conditions } \\
\hline GER & 9 & 34.4 & $\mathrm{~N} / \mathrm{A}$ \\
\hline
\end{tabular}

$C H D$ congenital heart disease, $A V S D$ atrioventricular septal defects, $V S D$ ventricular septal defect, $A S D$ atrial septal defect, $P D A$ patent ductus arteriosus, $O S A$ obstructive sleep apnea, $B P D$ bronchopulmonary dysplasia, GER gastroesophageal reflux N/A not available

L-to- R: systemic to pulmonary

${ }^{*}$ Case reports/case series

\section{Increased Hemodynamic Stress}

Congenital heart disease is present in $38-58 \%$ of individuals with DS, with likely genetic contributions (Table 1) [3-6, 14-16]. Children with DS are more likely to experience $\mathrm{PH}$ in the presence of CHD (38-80\%) than those with CHD who do not have DS (4-15\%) 
Table 3 Classification of pulmonary hypertension in individuals with Down syndrome [2]

\begin{tabular}{|c|c|c|c|}
\hline \multicolumn{3}{|c|}{ WHO classification group } & \multirow[t]{2}{*}{$\%(n=346)$} \\
\hline 1 & Pulmonary arterial hypertension & & \\
\hline & 1.4 .4 & CHD-associated PAH & 44.8 \\
\hline & 1.7 & PPHN & 35.3 \\
\hline 2 & PH due to left-sided heart disease & & 1.2 \\
\hline \multirow[t]{3}{*}{3} & PH caused by lung disease or hypoxemia & & \\
\hline & 3.4 & Sleep-disordered breathing & 17.9 \\
\hline & 3.5 & Developmental lung disease & $\wedge$ \\
\hline 4 & PH due to pulmonary arterial obstructions & & 0 \\
\hline \multirow[t]{3}{*}{5} & $\mathrm{PH}$ with unclear or multifactorial mechanisms & & \\
\hline & 5.3 & Thyroid disorders & 0 \\
\hline & 5.4 & Complex CHD & * \\
\hline
\end{tabular}

CHD congenital heart disease, PPHN persistent pulmonary hypertension of the newborn

${ }^{*}$ Referenced study precedes WSPH updates

$\wedge$ Biopsies not obtained

$[2,3,12,17,18]$. A left-to-right intracardiac shunt, in particular, increases the risk of developing PH in individuals with DS, with a relative risk of 2.1 (95\% CI 1.7-2.5; Table 2) [2]. Increases in pulmonary arterial blood flow through an intracardiac shunt can increase pulmonary arterial pressures, create shear stress, and contribute to endothelial dysfunction, vascular remodeling, and altered vasoactive mediator expression [19]. Left uncorrected, ventricular septal defects (VSD) and atrioventricular septal defects (AVSD) frequently progress to Eisenmenger syndrome, an end-stage reversal of the intracardiac shunt [17].

\section{Pulmonary Hypoplasia}

Several small case series have reported evidence of abnormal lung development or pulmonary hypoplasia in individuals with DS [20-22]. These autopsy reports have revealed evidence of increased pulmonary blood flow through dilated or congested pulmonary vasculature, and have revealed evidence of pulmonary arterial remodeling and noted disturbances in microvascular development. The overexpression of the human chromosome 21 (Hsa21)encoded antiangiogenic genes for endostatin (COL18a1), amyloid beta protein (APP), and regulator of calcineurin-1 (RCAN1) may contribute to impaired pulmonary vascular development [23]. Increased pulmonary blood flow to a pulmonary vascular bed with reduced capacitance may increase the risk of developing $\mathrm{PH}$, as it contributes to hemodynamic stress to the arterial endothelium and exacerbates hypoxia through impairments in diffusion and ventilation-to-perfusion matching.

\section{Intrinsic Endothelial Dysfunction}

The increased prevalence of PPHN and the existence of possible intrapulmonary bronchopulmonary anastomoses (IBA) in the population with DS may suggest an innate abnormality in endothelial function or vasomotor tone in the pulmonary circulation $[11,22]$. Reports of elevated endothelin-1 (ET-1; a potent vasoconstrictor) in children with DS who have CHD and reduced endothelial 
Table 4 Screening guidelines for children with Down syndrome and PH or at risk of developing PH (modified from Seattle Children's Hospital proposed guidelines) [41]

\begin{tabular}{|c|c|c|c|c|c|}
\hline & $\begin{array}{l}\text { AAP } \\
\text { standard of } \\
\text { care for all } \\
\text { patients with } \\
\text { Down } \\
\text { Syndrome }\end{array}$ & $\begin{array}{l}\text { Any child with } \\
\text { chronic } \\
\text { respiratory } \\
\text { symptoms or } \\
\text { conditions }\end{array}$ & $\begin{array}{l}\text { New PH } \\
\text { diagnosis or } \\
\text { recurrent } \\
\text { episode }\end{array}$ & $\begin{array}{l}\text { PH resolved or well } \\
\text { controlled }\end{array}$ & $\begin{array}{l}\text { No improvement in } \\
\mathrm{PH} / \text { worsening }\end{array}$ \\
\hline Echo & $\begin{array}{l}\text { First month } \\
\text { of life }\end{array}$ & $\begin{array}{l}\text { Consider } \\
\text { screening for } \\
\text { PH every year }\end{array}$ & $\begin{array}{r}\text { With initial } \\
\text { evaluation }\end{array}$ & $\begin{array}{l}\text { Annually until school age } \\
\text { for resolved } \mathrm{PH} \text { (CHD, } \\
\text { PPHN, or other cause } \\
\text { of } \mathrm{PH}) \\
\text { At least annually } \\
\text { indefinitely for well- } \\
\text { controlled PH }\end{array}$ & $\begin{array}{l}\text { As frequently as } \mathrm{PH} \text { team } \\
\text { suggests }\end{array}$ \\
\hline $\begin{array}{l}\text { Pulmonology } \\
\text { consult }\end{array}$ & $\mathrm{N} / \mathrm{A}$ & $\begin{array}{l}\text { Annual pediatric } \\
\text { pulmonology } \\
\text { evaluation }\end{array}$ & $\begin{array}{l}\text { With initial } \\
\text { evaluation } \\
\text { if not } \\
\text { previously } \\
\text { established }\end{array}$ & $\begin{array}{l}\text { Continue to follow } \\
\text { regularly until lung } \\
\text { disease ruled out as } \\
\text { contributing factor }\end{array}$ & $\begin{array}{l}\text { Continue to follow } \\
\text { regularly until lung } \\
\text { disease ruled out as } \\
\text { contributing factor }\end{array}$ \\
\hline VFSS & $\begin{array}{l}\text { In first year of } \\
\text { life only if } \\
\text { symptoms } \\
\text { present }\end{array}$ & $\begin{array}{l}\text { As soon as } \\
\text { respiratory } \\
\text { symptoms } \\
\text { become } \\
\text { apparent }\end{array}$ & $\begin{array}{r}\text { With initial } \\
\text { evaluation }\end{array}$ & $\begin{array}{l}\text { Annual evaluation by } \\
\text { speech-language } \\
\text { pathologist and VFSS } \\
\text { until age } 6 \text { years; } \\
\text { consider annual } \\
\text { screening thereafter for } \\
\text { those with history of } \\
\text { diagnosed aspiration }\end{array}$ & $\begin{array}{l}\text { At least annually (more } \\
\text { frequent if unexplained } \\
\text { worsening) }\end{array}$ \\
\hline Sleep study & By age 4 years & $\begin{array}{l}\text { Per primary } \\
\text { pulmonologist }\end{array}$ & $\begin{array}{r}\text { With initial } \\
\text { evaluation }\end{array}$ & $\begin{array}{l}\text { Consider annual sleep } \\
\text { clinic evaluation }\end{array}$ & $\begin{array}{l}\text { Annually, repeat after } \\
\text { any surgical airway } \\
\text { management }\end{array}$ \\
\hline $\begin{array}{l}\text { Chest CT } \\
\text { with and } \\
\text { without IV } \\
\text { contrast }\end{array}$ & $\mathrm{N} / \mathrm{A}$ & $\begin{array}{l}\text { Encouraged if } \\
\text { signs of lower } \\
\text { airway or } \\
\text { pulmonary } \\
\text { vascular disease }\end{array}$ & $\begin{array}{r}\text { With initial } \\
\text { evaluation }\end{array}$ & $\mathrm{N} / \mathrm{A}$ & $\begin{array}{l}\text { Consider repeating at } \\
\text { intervals decided with } \\
\text { primary pulmonologist } \\
\text { to screen for ongoing } \\
\text { evidence of aspiration, } \\
\text { other parenchymal } \\
\text { lung disease, or } \\
\text { pulmonary venous } \\
\text { obstruction }\end{array}$ \\
\hline
\end{tabular}


Table 4 continued

\begin{tabular}{|c|c|c|c|c|c|}
\hline & $\begin{array}{l}\text { AAP } \\
\text { standard of } \\
\text { care for all } \\
\text { patients with } \\
\text { Down } \\
\text { Syndrome }\end{array}$ & $\begin{array}{l}\text { Any child with } \\
\text { chronic } \\
\text { respiratory } \\
\text { symptoms or } \\
\text { conditions }\end{array}$ & $\begin{array}{l}\text { New PH } \\
\text { diagnosis or } \\
\text { recurrent } \\
\text { episode }\end{array}$ & $\begin{array}{l}\text { PH resolved or well } \\
\text { controlled }\end{array}$ & $\begin{array}{l}\text { No improvement in } \\
\mathrm{PH} / \text { worsening }\end{array}$ \\
\hline $\begin{array}{l}\text { Lab } \\
\text { surveillance: } \\
\text { BNP, } \\
\text { thyroid, } \\
\text { BMP, } \\
\text { autoimmune }\end{array}$ & $\begin{array}{l}\text { Thyroid: NB, } \\
6 \text { months, } \\
12 \text { months, } \\
\text { annually }\end{array}$ & $\begin{array}{l}\text { Consider BNP } \\
\text { with echo } \\
\text { screening, BMP } \\
\text { for } \\
\text { hypoventilation }\end{array}$ & $\begin{array}{l}\text { With initial } \\
\text { evaluation }\end{array}$ & At least annually & $\begin{array}{l}\text { At least annually, BNP } \\
\text { more frequently to } \\
\text { trend response to } \\
\text { treatment }\end{array}$ \\
\hline
\end{tabular}

AAP American Academy of Pediatrics, Echo echocardiogram, CHD congenital heart disease, VFSS video fluoroscopic swallow study, $C T$ computed tomography, $B N P$ brain-type natriuretic peptide, $B M P$ basic metabolic panel, $N B$ newborn, $P P H N$ persistent pulmonary hypertension of the newborn

production of nitric oxide (NO; a potent vasodilator) may be secondary to the overexpression and increased activity of four Hsa21encoded interferon receptors [24-27]. Interferon has negative modulatory effects on $\mathrm{NO}$ expression and can lead to upregulation of ET-1 [28]. The therapeutic use of interferon in the non-DS population has led to the development of $\mathrm{PAH}, \mathrm{a}$ frequent finding in disorders of genetic overexpression of interferon unrelated to DS [29-31].

\section{Increased Pulmonary Vascular Resistance}

Individuals with DS have a high incidence of respiratory comorbidities including obstructive sleep apnea (OSA), intermittent or sustained hypoxia, recurrent pneumonia, and chronic aspiration (Table 2) [2, 32]. Intermittent or chronic respiratory insults lead to regional or global hypoxic pulmonary vasoconstriction and may contribute to increases in pulmonary vascular resistance. Of particular interest, OSA has been reported in $45-79 \%$ of individuals with DS and has been implicated as a cause of $\mathrm{PH}$ in this population [33-37].

Congenital airway disorders are frequently reported in this population, particularly in those with chronic cough or recurrent respiratory infections. In children with DS undergoing endoscopic airway evaluations for these symptoms, airway abnormalities were identified in $14-75 \%$ of patients (Table 2) [38-40]. Commonly reported findings include tracheobronchomalacia and subglottic stenosis (acquired and congenital). A high incidence of tracheal bronchus (3-5\%) and laryngeal cleft (1\%) has also been reported in the population with DS, suggesting more obvious etiologies of recurrent pneumonia and aspiration, respectively [38, 40]. Consequential airway compression from cardiovascular abnormalities (e.g., cardiomegaly, vascular abnormalities) may be a complicating factor in those with CHD $[39,40]$. Airway disorders can contribute to intermittent hypoxia and impair one's ability to mobilize lower airway secretions, directly contributing to the increased risk of acquiring lower respiratory tract infections. These insults lead to transient or sustained increases in pulmonary vascular resistance and likely contribute to the higher incidence of $\mathrm{PH}$ observed in the population with DS. While direct evidence linking airway disease to the onset of $\mathrm{PH}$ is lacking in the population with DS, associations have been described, as the authors have previously 
Table 5 Managing conditions contributing to $\mathrm{PH}$ in individuals with DS

\begin{tabular}{|c|c|c|c|}
\hline Condition & Specialty & Evaluations & Possible interventions \\
\hline CHD & Cardiology & $\begin{array}{l}\text { Echocardiogram, cardiac } \\
\text { catheterization }\end{array}$ & $\begin{array}{l}\text { Pre-load reduction, surgical correction, } \\
\text { targeted vasodilator therapy }\end{array}$ \\
\hline PPHN & $\begin{array}{l}\text { Neonatology, } \\
\text { cardiology, } \\
\text { pulmonology }\end{array}$ & Echocardiogram & $\begin{array}{l}\text { Oxygen and ventilation support, targeted } \\
\text { vasodilator therapy }\end{array}$ \\
\hline OSA & $\begin{array}{l}\text { Pulmonology, sleep } \\
\text { provider }\end{array}$ & $\begin{array}{l}\text { Polysomnography, laryngoscopy, } \\
\text { bronchoscopy }\end{array}$ & $\begin{array}{l}\text { Surgical intervention, noninvasive } \\
\text { ventilation }\end{array}$ \\
\hline $\begin{array}{l}\text { Pulmonary } \\
\text { hypoplasia }\end{array}$ & Pulmonology & CT chest, lung biopsy & $\begin{array}{l}\text { Limit inflammatory insults, promote } \\
\text { growth }\end{array}$ \\
\hline Hypoxia & $\begin{array}{l}\text { Pulmonology, sleep } \\
\text { provider }\end{array}$ & $\begin{array}{l}\text { Polysomnography, CT chest, } \\
\text { echocardiogram, cardiac } \\
\text { catheterization }\end{array}$ & $\begin{array}{l}\text { Supplemental oxygen, improve pulmonary } \\
\text { toilet, ventilatory support, surgical } \\
\text { correction }\end{array}$ \\
\hline $\begin{array}{l}\text { Recurrent } \\
\text { pneumonia/ } \\
\text { aspiration }\end{array}$ & Pulmonology & $\begin{array}{l}\text { CT chest, bronchoscopy, swallow } \\
\text { evaluation }\end{array}$ & $\begin{array}{l}\text { Improve pulmonary toilet, treat cause of } \\
\text { aspiration }\end{array}$ \\
\hline $\begin{array}{l}\text { Airway disorders } \\
\text { (e.g., } \\
\text { tracheomalacia) }\end{array}$ & Pulmonology & CT chest, bronchoscopy & $\begin{array}{l}\text { Improve pulmonary toilet, ventilatory } \\
\text { support }\end{array}$ \\
\hline Thyroid disorders & Endocrinology & Serum TSH, free T4 & Levothyroxine \\
\hline
\end{tabular}

$C H D$ congenital heart disease, $P P H N$ persistent pulmonary hypertension of the newborn, $O S A$ obstructive sleep apnea, $C T$ computed tomography, TSH thyroid stimulating hormone

reported new diagnoses of OSA in $21 \%$ and recurrent pneumonia in $17 \%$ of children with DS prior to identifying a recurrence of their previously resolved PH [2]. Notably, large prospective studies evaluating respiratory comorbidities and risk for developing $\mathrm{PH}$ in the population with DS are lacking.

\section{Post-Capillary Disease}

Pulmonary vein stenosis has been reported to occur with increased frequency in the population with DS; however, the exact incidence is unknown [41-44]. Additionally, with the high frequency of CHD, there is likely an increase in disorders of left heart outflow, which can increase pulmonary vascular resistance and can contribute to the onset of $\mathrm{PH}$. Certain forms of
AVSD, such as single papillary muscle with deficient mural leaflet, frequently lead to increased left-sided AV valve stenosis or insufficiency causing or exacerbating pulmonary hypertension. Prospective, large-scale studies are necessary to identify the true incidence of left-sided heart disease and its contribution to $\mathrm{PH}$ onset (PH Group 2) in the population with DS.

\section{Screening}

There are currently no accepted screening guidelines for pulmonary hypertension in individuals with DS; however, a recent publication by the Pulmonary Hypertension Association has suggested a comprehensive approach (Table 4) [45]. Generally accepted guidelines 
remain limited to the screening of comorbid conditions including CHD (within the first month of life), valvular disease (between 13-21 years), sleep-disordered breathing (by age 4 years), and swallowing disorders (if ever symptomatic) [46]. When diagnosis is uncertain or targeted therapy is being considered, a cardiac catheterization is recommended by the American Heart Association and American Thoracic Society (AHA/ATS) [7]. Understandably, this is not always possible, and clinicians are encouraged to use their best clinical judgment when initiating therapies.

Recent work has identified possible biomarkers of $\mathrm{PH}$ specific to the population with DS including evidence of increased circulating inflammatory cells (immunomodulatory myeloid-derived suppressor cells and fibrocytes) [47] and dysregulated angiogenesis favoring antiangiogenesis (high serum levels of endostatin coupled with low levels of angiogenin) [48], although a subsequent study challenged endostatin's role as a biomarker in favor of the cardiac markers N-terminal prohormone of brain natriuretic peptide and galectin-3 [49]. These small studies were largely specific to the population with PAH (Group 1), and additional, more thorough investigations are needed.

Given the high frequency of disease in the population with DS, new biomarkers of early disease are needed. Echocardiography is an expensive test and identifies late evidence of pulmonary vascular disease (e.g., right ventricular hypertension) while cardiac catheterization is expensive, invasive, and not always feasible. Ongoing work should focus on risk stratification tools, evaluating hemodynamic stress in the vasculature, early or predictive protein signatures, or other biomarkers of early disease.

\section{Management}

The multiple underlying causes and risk factors for developing $\mathrm{PH}$ in the population with DS requires a multidisciplinary treatment approach. At a minimum, this should include pediatric cardiology, pediatric pulmonology, and relevant surgical subspecialties [45, 50]. Interventions should target the underlying cause of the disease both medically and surgically where appropriate (Table 5). Notably, addressing upper airway obstruction has been reported to improve mPAP on cardiac catheterization $[37,50]$. Additionally, given the complexity of the disorder, pre-anesthesia risk stratification specific to the population with DS may help guide safe surgical interventions [51].

In those patients with chronic respiratory symptoms, early referral to a comprehensive aerodigestive team may provide useful diagnostic insight or therapeutic opportunities to address underlying airway or digestive disorders that may contribute to the development of PH. Following American Academy of Pediatrics (AAP) screening recommendations for polysomnography may identify pathology and suggest referral to sleep or pulmonary specialists; however, a low threshold for referral to pulmonary specialists may provide additional benefit [45].

Early surgical correction is often necessary to prevent the development or progression of $\mathrm{PH}$ in individuals with DS who have CHD with systemic-to-pulmonary intracardiac shunts, including atrial septal defect (ASD) [52, 53]. Generally, surgical correction of CHD in individuals with DS is recommended by 2 years of age; however, preoperative hemodynamic assessment can aid in risk stratification of patients. In many centers, surgery is performed even earlier. A pulmonary vascular resistance index (PVRi) of $<6$ Wood units (WU) $\mathrm{m}^{-2}$ or $\geq 6 \mathrm{WU} \mathrm{m}^{-2}$ but with adequate reversibility (vasoreactivity with supplemental oxygen and inhaled NO with a reduction in PVRi $<6$ WU $\mathrm{m}^{-2}$ and pulmonary vascular resistance/ systemic vascular resistance $[\mathrm{PVR} / \mathrm{SVR}]<0.3$ ) response is associated with favorable outcomes [7]. Of note, there have been reports of increases in postoperative $\mathrm{PH}$ in children with DS undergoing surgical repair for both ASD $(1.7 \%$ vs. $0.2 \%)$ and VSD (2.2\% vs. $0.7 \%)$ compared to non-DS controls [54].

For individuals with DS who have intrinsic disease of the pulmonary arteries such as $\mathrm{PAH}$ associated with $\mathrm{CHD}$ or PPHN, targeted $\mathrm{PH}$ pharmacotherapies can be considered. There are very few studies evaluating pharmacotherapies specifically in the population with DS; however, 
the studies available and sub-analyses of general $\mathrm{PAH}$ population studies have suggested that endothelin receptor antagonists (ERA) can improve quality of life, exercise capacity, and functional classification, and have been generally well tolerated [55-59]. The phosphodiesterase-5 inhibitor sildenafil may not be as efficacious as ERA, as a suboptimal improvement in pulmonary vascular resistance index and MPAP was reported in a DS-specific subanalysis of the STARTS-1 trial [60]. This study did report that the drug was well tolerated in this population, but did not evaluate for confounding comorbidities or causes of $\mathrm{PH}$ in the population with DS involved. Dosing for pediatric [7] and adult [61] targeted therapies can be found elsewhere. Of note, as of the writing of this manuscript, in the United States, the only Food and Drug Administration-approved medication for PAH in children is the ERA bosentan.

\section{Future Areas of Research}

With updated classifications and a more inclusive definition for pulmonary hypertension, it stands to reason that more people with DS will be diagnosed with $\mathrm{PH}$. Large prospective cohort studies are required to better understand the prevalence and risk factors contributing to the development of $\mathrm{PH}$ in individuals with DS. Screening for the condition may be improving, as novel biomarkers have been identified and are currently under investigation [47, 62]. Ongoing $\mathrm{PH}$ registries are improving our understanding of how individuals with DS respond to targeted therapies; however, therapeutic studies specific to the population with DS are needed, including those that evaluate the response to treating cardiac and respiratory comorbidities.

Preclinical mouse models of lung disease in the population with DS may prove valuable in studying mechanisms of disease and isolating genetic contributions to the onset of $\mathrm{PH}$ [63]. While the mouse orthologues for human chromosome 21 are distributed across three murine chromosomes (Mm10, Mm16, and Mm17), complicating preclinical studies, a trisomic Mm16 (Dp16) mouse, when raised in hypoxic conditions, develops the hypoplastic pulmonary phenotype and has evidence of pulmonary hypertension (data presented in the form of $\mathrm{n}$ platform presentation by Bush et al. at the American Thoracic Society International Conference, 2017).

\section{CONCLUSIONS}

$\mathrm{PH}$ in the population with DS appears to be more common than that in the population without DS. There are multifactorial reasons for the higher prevalence of $\mathrm{PH}$ in this population including abnormal pulmonary development, increased hemodynamic stress in the pulmonary vasculature, capillary and post-capillary obstructive disorders, and inflammatory and possibly metabolic contributions [64]. Additional large-scale epidemiologic and clinical investigations are needed to understand the impact of this disease on this vulnerable population, and ongoing basic and translational science is required to identify biomarkers of early pulmonary vascular disease, understand genetic and molecular pathways, and evaluate effective targeted therapies.

\section{ACKNOWLEDGEMENTS}

Funding. No funding or sponsorship was received for this study or publication of this article.

Authorship. All named authors meet the International Committee of Medical Journal Editors (ICMJE) criteria for authorship for this article, take responsibility for the integrity of the work as a whole, and have given their approval for this version to be published.

Author Contributions. All authors co-wrote, read, reviewed and approved the final manuscript.

Disclosures. Douglas Bush has nothing to disclose. Dunbar Ivy has nothing to disclose. 
Compliance with Ethics Guidelines. This manuscript is based on previously conducted studies and does not contain any new studies with human participants, or animals, performed by any of the authors.

Open Access. This article is licensed under a Creative Commons Attribution-NonCommercial 4.0 International License, which permits any non-commercial use, sharing, adaptation, distribution and reproduction in any medium or format, as long as you give appropriate credit to the original author(s) and the source, provide a link to the Creative Commons licence, and indicate if changes were made. The images or other third party material in this article are included in the article's Creative Commons licence, unless indicated otherwise in a credit line to the material. If material is not included in the article's Creative Commons licence and your intended use is not permitted by statutory regulation or exceeds the permitted use, you will need to obtain permission directly from the copyright holder. To view a copy of this licence, visit http://creativecommons.org/licenses/by$\mathrm{nc} / 4.0 /$.

\section{REFERENCES}

1. Naumburg E, Soderstrom L, Huber D, Axelsson I. Risk factors for pulmonary arterial hypertension in children and young adults. Pediatr Pulmonol. 2017;52:636-41.

2. Bush D, Galambos C, Ivy DD, Abman SH, WolterWarmerdam K, Hickey F. Clinical characteristics and risk factors for developing pulmonary hypertension in children with Down syndrome. J Pediatr. 2018;202:212-9.

3. Espinola-Zavaleta N, Soto ME, Romero-Gonzalez A, Gomez-Puente Ldel C, Munoz-Castellanos L, Gopal AS, et al. Prevalence of congenital heart disease and pulmonary hypertension in Down's syndrome: an echocardiographic study. J Cardiovasc Ultrasound. $2015 ; 23: 72-7$.

4. Weijerman ME, van Furth AM, van der Mooren MD, van Weissenbruch MM, Rammeloo L, Broers CJ, et al. Prevalence of congenital heart defects and persistent pulmonary hypertension of the neonate with Down syndrome. Eur J Pediatr. 2010;169: 1195-9.

5. Cullum L, Liebman J. The association of congenital heart disease with Down's syndrome (mongolism). Am J Cardiol. 1969;24:354-7.

6. Freeman SB, Bean LH, Allen EG, Tinker SW, Locke $\mathrm{AE}$, Druschel C, et al. Ethnicity, sex, and the incidence of congenital heart defects: a report from the National Down Syndrome Project. Genetics Med. 2008;10:173-80.

7. Abman SH, Hansmann G, Archer SL, Ivy DD, Adatia I, Chung WK, et al. Pediatric Pulmonary Hypertension: Guidelines From the American Heart Association and American Thoracic Society. Circulation. 2015;132:2037-99.

8. Colquitt JL, Morris SA, Denfield SW, Fraser CD, Wang Y, Kyle WB. Survival in children with Down syndrome undergoing single-ventricle palliation. Ann Thorac Surg. 2016;101:1834-41.

9. O'Leary L, Hughes-McCormack L, Dunn K, Cooper SA. Early death and causes of death of people with Down syndrome: a systematic review. J Appl Res Intellect Disabil. 2018;31:687-708.

10. Yang Q, Rasmussen SA, Friedman JM. Mortality associated with Down's syndrome in the USA from 1983 to 1997: a population-based study. Lancet. 2002;359:1019-25.

11. Cua CL, Blankenship A, North AL, Hayes J, Nelin LD. Increased incidence of idiopathic persistent pulmonary hypertension in Down syndrome neonates. Pediatr Cardiol. 2007;28:250-4.

12. Mourato FA, Villachan LR, Mattos SS. Prevalence and profile of congenital heart disease and pulmonary hypertension in Down syndrome in a pediatric cardiology service. Rev Paul Pediatr. 2014;32:159-63.

13. Rosenzweig EB, Abman SH, Adatia I, Beghetti M, Bonnet D, Haworth S, et al. Paediatric pulmonary arterial hypertension: updates on definition, classification, diagnostics and management. Eur Respir J. 2018;53:1801916.

14. de Rubens FJ, del Pozzo MB, Pablos Hach JL, Calderon Jimenez C. Castrejon Urbina R [Heart malformations in children with Down syndrome]. Rev Esp Cardiol. 2003;56:894-9.

15. Li H, Cherry S, Klinedinst D, DeLeon V, Redig J, Reshey B, et al. Genetic modifiers predisposing to congenital heart disease in the sensitized Down syndrome population. Circ Cardiovasc Genet. 2012;5:301-8. 
16. Alharbi KM, Al-Mazroea AH, Abdallah AM, Almohammadi Y, Carlus SJ, Basit S. Targeted next-generation sequencing of 406 genes identified genetic defects underlying congenital heart disease in Down syndrome patients. Pediatr Cardiol. 2018;39: 1676-80.

17. Duffels MG, Engelfriet PM, Berger RM, van Loon RL, Hoendermis E, Vriend JW, et al. Pulmonary arterial hypertension in congenital heart disease: an epidemiologic perspective from a Dutch registry. Int J Cardiol. 2007;120:198-204.

18. Greenwood RD, Nadas AS. The clinical course of cardiac disease in Down's syndrome. Pediatrics. 1976;58:893-7.

19. Adatia I, Kothari SS, Feinstein JA. Pulmonary hypertension associated with congenital heart disease: pulmonary vascular disease: the global perspective. Chest. 2010;137:52S-61S.

20. Cooney TP, Thurlbeck WM. Pulmonary hypoplasia in Down's syndrome. N Engl J Med. 1982;307: 1170-3.

21. Betsy L, Schloo M, Gordon F, Vawter M, Lynn M, Reid M. Down syndrome: patterns of disturbed lung growth. Human Pathol. 1990;22:919-23.

22. Bush D, Abman SH, Galambos C. Prominent intrapulmonary bronchopulmonary anastomoses and abnormal lung development in infants and children with Down syndrome. J Pediatr. 2017;180:15662e1.

23. Galambos C, Minic AD, Bush D, Nguyen D, Dodson $B$, Seedorf $G$, et al. Increased lung expression of anti-angiogenic factors in Down syndrome: potential role in abnormal lung vascular growth and the risk for pulmonary hypertension. PLOS ONE. 2016;11:0159005.

24. Kageyama K, Hashimoto S, Nakajima Y, Shime N, Hashimoto S. The change of plasma endothelin-1 levels before and after surgery with or without Down syndrome. Paediatr Anaesth. 2007;17: 1071-7.

25. Aoki M, Hirono K, Higuma T, Suzuki Y, Nakayama $\mathrm{K}$, Yamashita A, et al. Pulmonary vascular disease in a failed Fontan patient with Down's syndrome. Gen Thorac Cardiovasc Surg. 2018;66:299-302.

26. Cappelli-Bigazzi M, Santoro G, Battaglia C, Palladino MT, Carrozza M, Russo MG, et al. Endothelial cell function in patients with Down's syndrome. Am J Cardiol. 2004;94:392-5.

27. Sullivan KD, Lewis HC, Hill AA, Pandey A, Jackson LP, Cabral JM, et al. Trisomy 21 consistently activates the interferon response. Elife. 2016;5.
28. Buie JJ, Renaud LL, Muise-Helmericks R, Oates JC. IFN-alpha negatively regulates the expression of endothelial nitric oxide synthase and nitric oxide production: implications for systemic lupus erythematosus. J Immunol. 2017;199:1979-88.

29. George PM, Oliver E, Dorfmuller P, Dubois OD, Reed DM, Kirkby NS, et al. Evidence for the involvement of type I interferon in pulmonary arterial hypertension. Circ Res. 2014;114:677-88.

30. Papani R, Duarte AG, Lin YL, Kuo YF, Sharma G. Pulmonary arterial hypertension associated with interferon therapy: a population-based study. Multidiscip Respir Med. 2017;12:1.

31. Adang LA, Frank DB, Gilani A, Takanohashi A, Ulrick N, Collins A, et al. Aicardi goutieres syndrome is associated with pulmonary hypertension. Mol Genet Metab. 2018;125:351-8.

32. McDowell KM, Craven DI. Pulmonary complications of Down syndrome during childhood. J Pediatr. 2011;158:319-25.

33. Marcus CL, Keens TG, Bautista DB, von Pechmann WS, Ward SL. Obstructive sleep apnea in children with Down syndrome. Pediatrics. 1991;88:132-9.

34. Maris M, Verhulst S, Wojciechowski M, Van de Heyning P, Boudewyns A. Prevalence of Obstructive Sleep Apnea in Children with Down Syndrome. Sleep. 2016;39:699-704.

35. Dyken ME, Lin-Dyken DC, Poulton S, Zimmerman $\mathrm{MB}$, Sedars E. Prospective polysomnographic analysis of obstructive sleep apnea in Down syndrome. Arch Pediatr Adolesc Med. 2003;157:655-60.

36. Ayeni TI, Roper HP. Pulmonary hypertension resulting from upper airways obstruction in Down's syndrome. J R Soc Med. 1998;91:321-2.

37. Loughlin GM, Wynne JW, Victorica BE. Sleep apnea as a possible cause of pulmonary hypertension in Down syndrome. J Pediatr. 1981;98:435-7.

38. De Lausnay M, Verhulst S, Boel L, Wojciechowski M, Boudewyns A, Van Hoorenbeeck K. The prevalence of lower airway anomalies in children with Down syndrome compared to controls. Pediatr Pulmonol. 2020;55:1259-63.

39. Bertrand P, Navarro H, Caussade S, Holmgren N, Sanchez I. Airway anomalies in children with Down syndrome: endoscopic findings. Pediatr Pulmonol. 2003;36:137-41.

40. Hamilton J, Yaneza MM, Clement WA, Kubba H. The prevalence of airway problems in children with Down's syndrome. Int J Pediatr Otorhinolaryngol. 2016;81:1-4. 
41. Gowda S, Bhat D, Feng Z, Chang CH, Ross RD. Pulmonary vein stenosis with Down syndrome: a rare and frequently fatal cause of pulmonary hypertension in infants and children. Congenit Heart Dis. 2014;9:E90-7.

42. Ooi YK, Sinha P, Gierdalski M, Harahsheh A. Highrisk single ventricle palliation in children with Down syndrome: single institution experience. Cardiol Young. 2015;25:539-43.

43. Nasr VG, Callahan R, Wichner Z, Odegard KC, DiNardo JA. Intraluminal Pulmonary Vein Stenosis in Children: A "New" Lesion. Anesth Analg. 2019;129:27-40.

44. Seale AN, Webber SA, Uemura H, Partridge J, Roughton M, Ho SY, et al. Pulmonary vein stenosis: the UK, Ireland and Sweden collaborative study. Heart. 2009;95:1944-9.

45. Jackson EO, Davis A. PH Professional Network: Comprehensive evaluation and ongoing approach to children with Down syndrome who have pulmonary hypertension or are at risk of developing pulmonary hypertension. Adv Pulm Hypertens. 2019;18:37-9.

46. Bull MJ. Committee on G. Health supervision for children with Down syndrome. Pediatrics. 2011;128:393-406.

47. Colvin KL, Ivy DD, Yeager ME. Altered Peripheral Blood Myeloid Cell Subpopulations in Children With Down Syndrome and Pulmonary Hypertension. J Pediatr Hematol Oncol. 2017;39:158-9.

48. Bush D, Wolter-Warmerdam $\mathrm{K}$, Wagner BD, Galambos C, Ivy DD, Abman S, et al. EXPRESS: Angiogenic Profile Identifies Pulmonary Hypertension in Children with Down Syndrome. Pulmonary circulation. 2019:2045894019866549.

49. Griffiths M, Yang J, Vaidya D, Nies M, Brandal S, Ivy DD, et al. Biomarkers of Pulmonary Hypertension Are Altered in Children with Down Syndrome and Pulmonary Hypertension. J of Pediatr. 2021.

50. Hawkins A, Langton-Hewer S, Henderson J, Tulloh RM. Management of pulmonary hypertension in Down syndrome. Eur J Pediatr. 2011;170:915-21.

51. Lewanda AF, Matisoff A, Revenis M, Harahsheh A, Futterman C, Nino G, et al. Preoperative evaluation and comprehensive risk assessment for children with Down syndrome. Paediatr Anaesth. 2016;26: 356-62.

52. Balint $\mathrm{OH}$, Samman A, Haberer $\mathrm{K}$, Tobe L, McLaughlin P, Siu SC, et al. Outcomes in patients with pulmonary hypertension undergoing percutaneous atrial septal defect closure. Heart. 2008;94:1189-93.

53. Iwaya $Y$, Muneuchi J, Inoue $Y$, Watanabe M, Okada S, Ochiai Y. Relationship between pulmonary arterial resistance and compliance in patients with Down syndrome. Pediatr Cardiol. 2019;40:841-7.

54. Fudge JC Jr, Li S, Jaggers J, O’Brien SM, Peterson ED, Jacobs JP, et al. Congenital heart surgery outcomes in Down syndrome: analysis of a national clinical database. Pediatrics. 2010;126:315-22.

55. Duffels MG, Vis JC, van Loon RL, Berger RM, Hoendermis ES, van Dijk AP, et al. Down patients with Eisenmenger syndrome: is bosentan treatment an option? Int J Cardiol. 2009;134:378-83.

56. Serino G, Guazzi M, Micheletti A, Lombardi C, Danesi R, Negura D, et al. Effect of bosentan on exercise capacity and clinical worsening in patients with dual Down and Eisenmenger syndrome. Clin Med Insights Cardiol. 2013;7:29-34.

57. Duffels MG, Vis JC, van Loon RL, Nieuwkerk PT, van Dijk AP, Hoendermis ES, et al. Effect of bosentan on exercise capacity and quality of life in adults with pulmonary arterial hypertension associated with congenital heart disease with and without Down's syndrome. Am J Cardiol. 2009;103: 1309-15.

58. Kermeen FD, Franks C, O'Brien K, Seale H, Hall K, $\mathrm{McNeil} \mathrm{K}$, et al. Endothelin receptor antagonists are an effective long term treatment option in pulmonary arterial hypertension associated with congenital heart disease with or without trisomy 21 . Heart Lung Circ. 2010;19:595-600.

59. D'Alto M, Romeo E, Argiento P, D'Andrea A, Sarubbi B, Correra A, et al. Therapy for pulmonary arterial hypertension due to congenital heart disease and Down's syndrome. Int J Cardiol. 2013;164: 323-6.

60. Beghetti M, Rudzinski A, Zhang M. Efficacy and safety of oral sildenafil in children with Down syndrome and pulmonary hypertension. BMC Cardiovasc Disord. 2017;17:177.

61. Klinger JR, Elliott CG, Levine DJ, Bossone E, Duvall L, Fagan K, et al. Therapy for pulmonary arterial hypertension in adults: update of the CHEST guideline and expert panel report. Chest. 2019;155: $565-86$.

62. Bush D, Wolter-Warmerdam $\mathrm{K}$, Wagner BD, Galambos C, Ivy DD, Abman S, et al. EXPRESS: Angiogenic Profile Identifies Pulmonary Hypertension in Children with Down Syndrome.0: 2045894019866549. 
63. Gupta M, Dhanasekaran AR, Gardiner KJ. Mouse models of Down syndrome: gene content and consequences. Mamm Genome. 2016;27:538-55.
64. Bush D, Galambos C, Dunbar Ivy D. Pulmonary hypertension in children with Down syndrome. Pediatric pulmonology. 2020. 